\title{
Risk Behaviour on the Internet in the Context of Loneliness in Adolescents
}

\section{Andrea Vašková \\ Soňa Lovašová}

Pavol Jozef Šafárik University in Košice

\begin{abstract}
The aim of this paper at the theoretical level was to characterize risk behaviour on the Internet including its forms. In the theoretical part of the paper, the authors clarified, among other things, the issue of loneliness and outlined the most common causes of loneliness. The authors defined loneliness from the viewpoint of adolescence as a developmental period. At the empirical level, the aim of the authors was to identify differences in the incidence of risk behaviour on the Internet in adolescents in terms of their socio-demographic characteristics. Another goal was to point out the correlations between risk behaviour on the Internet and loneliness.
\end{abstract}

Keywords: Risk Behaviour on the Internet, Internet, Loneliness, Adolescence, Adolescents, Forms of Risk Behaviour on the Internet

\section{Introduction}

The Internet and the risks it poses globally cannot be considered brand new, but they remain highly topical. Most research focused on experiencing loneliness so far has indicated that risk behaviour on the Internet may occur as a result of individual loneliness, which represents a predictor of risk behaviour and risky use of the Internet (Caplan, 2007; Ceyhan a Ceyhan, 2008; Kim, LaRose a Peng, 2009; Morahan a Schumacher, 2003). Only few studies have investigated the relationship between loneliness and risky use of the Internet from the opposite direction. Some studies focused on specific forms of risk behaviour as a predictor of experiencing loneliness (Yoder, Virden and Amin, 2005). Banerjee and Rai (2020) have pointed out that significant social-economic, political, and psychosocial impacts from the current situation can be observed. Billions of people were quarantined to contain the infection. However, social isolation leads to chronic loneliness and boredom, which may have negative effects on physical and mental well-being (Banerjee and Rai, 2020). In such situations, an individual seeks substitute resources to eliminate loneliness. The Internet belongs among these resources as an inseparable part of not only adults' but also adolescents' lives today. These times are marked with changes, which affect everyone. COVID-19 is being addressed not only in medicine, but also in humanities and social sciences. It is because COVID-19 is closely connected with social isolation. Adolescents had to adapt to the online environment in education and started using the Internet even more than before. The information and communication technologies (ICT) have truly become an inseparable part of their everyday life. Social interaction with teachers, classmates and friends shifted suddenly and unexpectedly moved to the Internet. What is the impact of this change on adolescents' mental 
health and the development of their personal identity? This paper clarifies the relationship between risk behaviour on the Internet and loneliness. The level of loneliness experienced before the COVID-19 pandemic started will be described in the discussion. Other changes related to the current situation will be pointed out and this study will be compared with previous research.

\section{Risk behaviour on the Internet}

Risk behaviour on the Internet in the context of adolescence can be described as participation in situations, which increase the probability that the adolescent's personality or other people will be negatively affected. These negative effects include emotional issues, victimisation, deterioration of social or academic performance (Valcke et al., 2011).

Risk behaviour on the Internet can be addressed from a number of viewpoints as the Internet provides a broad variety of possible uses. It means that adolescents can engage in risk behaviour in a range of areas on the Internet. All these areas would be impossible to address in a single study. Therefore, this research focused on the activities performed most frequently by adolescents on the Internet that pose a potential risk. Hamburger and Artzi (2003) have pointed out that people use the Internet in different ways based on their personal preference.

The research performed by Gregusová, Tomková and Balážová (2010) has identified gender differences in the activities performed by adolescents on the Internet. They found that girls prefer to chat and engage in social networks while boys prefer playing online games. In terms of risks, boys may be more at risk from online game or pornography addiction as well as online shopping scams. Girls are more at risk from interaction with other people on social networks. Such risks include sexual harassment and contact with sexual aggressors. Benkovič (2007) has stated that the most frequently visited websites relate to gambling and dating.

\section{Types of risk behaviour on the Internet}

From the psychopathological point of view, risk behaviour can be divided into these categories:

behavioural disorders

mental disorders and behavioural disorders caused by the use of psychoactive substances

habit and impulse disorders

non-addictive substance abuse

disorders related to sexual object preference (Čerešník a Gatial, 2014)

However, this categorisation is not ideal, as some potential risk behaviour areas are missing. For example, non-substance addiction such as Internet addiction, social network addiction, shopaholism, etc. These issues pose mainly a social and interactional risk (Čerešník a Gatial, 2014).

Another risk behaviour categorisation specifies two basic groups. The first one includes behaviour causing mental and physical issues in adolescents, and the second one is related to the influence created by other people and often associated with social risk (Macek, 2003).

The concept of risk behaviour usually includes non-substance addictions such as gambling, ICT misuse, etc. (Miovský et al., 2010). Besides general divisions, ICT-related categorisations 
have been emerging recently. The "new" forms of risk behaviour have been defined. They result from modern communication addictions which represent the primary consequences of this type of risk behaviour (Lichner and Šlosár, 2017). Young (1999) has determined four categories of specific Internet addiction forms: They include virtual sex addiction, virtual relationship addiction, online gambling and shopping addiction, information addiction, and computer addiction.

The basic characteristics of non-substance addictions are very similar to the best known nonsubstance addiction so far, a habit and impulse disorder - pathological gambling. It includes these symptoms:

strong desire for pleasant experience and deep involvement

difficulty controlling the activity

preferring the activity to other activities

performing the activity despite emerging problems (Benkovič, 2007)

The progress in society reflecting the development of ICT along with premature adolescence should not be used as an apology or explanation for the adolescent's failures. Instead of creating specific primary prevention programmes focused on a single problem, it is necessary to focus on development and support of the adolescent's personality. Proper attention should be paid to developing social skills so that the adolescent learns to realize they are responsible for their own behaviour (Madro a Kohút, 2016).

For this research, Blinka's categorisation (2015) of the Internet areas in which problems may arise will be used

virtual sexuality

virtual relationships

information

social networks

computer addiction

These components cannot be referred to as risk behaviour on the Internet as such since, they merely refer to categories that pose a risk. However, their individual characteristics integrate the symptoms of risk behaviour on the Internet. Virtual sexuality as such is not considered risk behaviour on the Internet, but some of its manifestations are. For example, the overuse of pornographic websites, sharing nudes in private messages or publishing them on public websites. Risk behaviour in virtual relationships may manifest as complete involvement, preferring them to real-life relationships and the inability to see the difference, or using a false identity to establish virtual friendships. Information-related risks include the urge to constantly look for information, trust in disinformation, misusing information for one's own benefit, etc. The main point of social networks is to facilitate communication. In this area, risk behaviour includes excessive communication in the virtual environment at the expense of real-life, aggressive, vulgar, and other negative forms of communication. Internet compulsions are also an interesting phenomenon in the virtual environment; this term refers to excessive online gaming, unregulated online shopping, etc. (Blinka 2015, Young 1999). 
Risk behaviour on the Internet also includes cyberbullying and real-life meetings with people met in the online environment (Guadix-Gámez, Borrajo a Almendros, 2016). Paluckaitė and Matulaitienè (2016) have divided risk behaviour on the Internet into five basic forms: risky sexual behaviour, communication with strangers, sharing personal information, cyberbullying, and access to age-inappropriate websites.

To sum up, specialised literature offers numerous categorisations of risk behaviour on the Internet. Some of them overlap while some do not. However, all of them share one attribute the presence of negative phenomena frequently faced by adolescents. A negative phenomenon refers to any negative content or behaviour across which the adolescent may come in the virtual environment.

\section{Loneliness in adolescents}

Today, adolescents can use a variety of ways to interact with other people. They can use anything from text messages and online social networks to extracurricular activities to socialize. However, their feelings of loneliness and isolation are increasing. Many adolescents have stated that they feel lonely even in the presence of their family and friends (Margalit, 2011).

Peplau and Perlman (1982) have characterised loneliness using three characteristics:

loneliness is subjective - it results from our own interpretation of events

loneliness can be seen as a consequence of certain deficiencies in interpersonal relationships

loneliness is unpleasant

Intense physical, cognitive, or emotional developmental experience, an identity crisis, or the need for individualisation and autonomy may lead the adolescent to experience loneliness. There are also individual attributes that may enhance loneliness. For example, low selfrespect, deficient social skills or self-confidence, unrealistic expectations from social relationships, and frequent conflicts with parents (Tabak and Zawadzka, 2017).

A partial goal of this study is to seek appropriate intervention to eliminate loneliness resulting from risk behaviour on the Internet. It is of key importance to find out why the adolescent escapes into the virtual environment in the first place, because their reasons are the primary factors affecting the emergence of further issues resulting from the adolescent's decisions.

\section{Research}

The primary goal of this research was to empirically identify the correlation between risk behaviour on the Internet and loneliness. It also aimed to identify the differences in incidence of risk behaviour on the Internet in terms of sociodemographic characteristics of adolescents. Last but not least, the research focused on identifying predictions for risk behaviour on the Internet related to loneliness in adolescents.

This part of the paper describes the research performed and the methods applied.

\section{Methodology}

The research was performed using quantitative methodology. A questionnaire was used to perform quantitative research. The questionnaire battery consisted of multiple parts. The first part aimed to collect data on risk behaviour on the Internet, the second part identified the level 
of loneliness, and the third part focused on demographic data and other information necessary for the research.

A Risk Behaviour on the Internet (RBI) questionnaire created by the authors themselves (Vašková and Lovašová, 2020) was used to identify the incidence of specific forms of risk behaviour on the Internet. The respondents were asked to mark their answer on a 6-point scale (1-Never to 6-Always). The Cronbach's alpha of the RBI questionnaire was 0.885 . It consists of 37 items divided into 3 basic dimensions. The three dimensions integrate different forms of risk behaviour on the Internet.

Virtual sexuality - overuse of pornographic websites, sharing nudes in private messages or publishing them on public websites. (Cronbach's alpha $=0.785$ )

Social networks - excessive communication in the virtual environment at the expense of reallife, aggressive, vulgar, and other negative forms of communication. (Cronbach's alpha=0.796)

Internet compulsions - excessive online gaming, unregulated online shopping. (Cronbach's alpha $=0.783$ )

The standardised UCLA loneliness scale (Russell, 1996) was used to identify the level of loneliness experienced in adolescents. The scale consists of twenty statements measuring the subjective feeling of loneliness and social isolation. Half of the statements reflect satisfaction with social relationships and half reflect dissatisfaction. The respondents can mark the answer on a 4-point scale (1-Never to 6-Always). The Cronbach's alpha of the original UCLA scale was $0.89-0.94$. The Cronbach's alpha measured by the research team was 0.89 .

The questionnaire battery also included sociodemographic characteristics necessary for the purpose of the research.

\section{Research file characteristics}

The research sample consisted of 200 respondents. 124 female and 76 male respondents participated. The respondents were selected using cluster random sampling. The gender distribution of the research sample can be seen in the chart below.

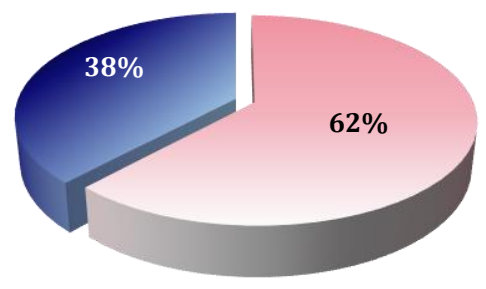

Female Male

The sample was also divided according to age. The research file included adolescents in middle to late adolescence, i.e. 13-21 years of age. The age distribution can be seen in Table 1. The average age of the research sample was 16.62 years. 


\begin{tabular}{|c||c|}
\hline Age & f \\
\hline \hline 13 & 1 \\
\hline 14 & 14 \\
\hline 15 & 28 \\
\hline 16 & 57 \\
\hline 17 & 45 \\
\hline 18 & 35 \\
\hline 19 & 14 \\
\hline 20 & 4 \\
\hline 21 & 2 \\
\hline
\end{tabular}

\section{Statistical processing of the results and their interpretation}

In this part of the paper, the research will be presented. It focused on (1) gender differences and (2) age differences in the behaviour on the Internet. Besides differences, correlations between loneliness and individual dimensions of risk behaviour on the Internet were investigated. A combination of correlation and causal-comparative research methodology was used and the results were processed using the SPSS statistical program. Results can be seen in the tables below.

The first part of the questionnaire aimed to identify the rate of risk behaviour on the Internet in adolescents using the authors' own RBI questionnaire. The respondents with higher scores showed higher rates of risk behaviour on the Internet. The respondents with lower scores showed lower rates of risk behaviour on the Internet. The maximum and minimum scores were 222 and 37 respectively. The average value of the answers on the scale from 1-Never to 6-Always in the research sample was 1.94.

The second part of the questionnaire aimed to identify the level of loneliness in adolescents. The maximum and minimum scores were 80 and 20 respectively. The higher the score, the higher the level of loneliness. The average score in the questionnaire focused on the subjective feeling of loneliness was 2.18 .

\section{Gender differences in the incidence of risk behaviour on the Internet}

The Mann-Whitney $U$ test for two independent samples $(Z=-0.329)$ was used to identify gender differences in the incidence of risk behaviour on the Internet. The table below shoes that $p(\alpha)=0.742$, therefore no statistically significant difference in terms of gender could be observed. Females in this research demonstrated more risk behaviour on the Internet than males, but the difference is insignificant. It can be stated that there are no statistically significant gender differences in risk behaviour on the Internet, although certain differences can be observed.

\begin{tabular}{|c||c|c|c|c|c|c|c|}
\hline & Gender & $\mathrm{N}$ & $\mathrm{Med}(\mathrm{x})$ & $\mathrm{X}$ & $\mathrm{U}$ & $\mathrm{Z}$ & $\mathrm{p}(\alpha)$ \\
\hline \hline \multirow{2}{*}{$\begin{array}{c}\text { Risk behaviour on the } \\
\text { Internet }\end{array}$} & Female & 124 & 0.47 & 1.95 & 4581.5 & -0.329 & 0.742 \\
\cline { 2 - 8 } & Male & 76 & 0.38 & 1.92 & & & \\
\hline
\end{tabular}




\section{Age differences in the incidence of risk behaviour on the Internet}

Besides gender differences, age differences in risk behaviour on the Internet were also investigated using the Kruskal-Wallis test for multiple samples. Age differences in the incidence of risk behaviour on the Internet do exist as shown by this research, $p(\alpha)=0.034$ indicates a statistically significant difference. The results indicated the highest rate of risk behaviour in fourteen year old $(X=2.41)$ and the lowest rate in twenty-one year old adolescents $(X=1.56)$. It could be explained by the fact that at the point when early adolescence turns into middle adolescence at 14 , major puberty-related changes are taking place. During this period, the interest in peers of the opposite sex increases and cognitive processes are developing. Erikson (in Langmeier and Krejčířová, 1998) has stated that at this time, adolescents face feelings of insecurity, self-doubt and doubt their place in society. In the context of fighting these feelings of insecurity and self-doubt, the adolescent may think the Internet the most suitable place to solve their problems. On the other hand, in 21-year-old adolescents, the social aspect of their identity is significantly enhanced.

\begin{tabular}{|c|c|c|c|c|c|c|}
\hline \multirow{10}{*}{$\begin{array}{c}\text { Risk } \\
\text { behaviour } \\
\text { on the } \\
\text { Internet }\end{array}$} & age & $\mathrm{N}$ & $\operatorname{Med}(\mathrm{x})$ & $\mathrm{X}$ & $\chi$ & $\mathrm{p}(\alpha)$ \\
\hline & 13 & 1 & 2.02 & 2.02 & \multirow{9}{*}{16.66} & \multirow{9}{*}{0.034} \\
\hline & 14 & 14 & 1.94 & 2.41 & & \\
\hline & 15 & 28 & 1.90 & 1.91 & & \\
\hline & 16 & 57 & 2.02 & 2.02 & & \\
\hline & 17 & 45 & 1.91 & 1.86 & & \\
\hline & 18 & 35 & 1.78 & 1.80 & & \\
\hline & 19 & 14 & 1.75 & 1.85 & & \\
\hline & 20 & 4 & 1.61 & 1.80 & & \\
\hline & 21 & 2 & 1.56 & 1.56 & & \\
\hline
\end{tabular}

The correlations between loneliness and individual dimensions of risk behaviour on the Internet

For the purpose of investigating the correlations between loneliness and the "social networks" dimension, the Spearman's rank correlation coefficient for non-parametric statistics was used. The value of the correlation coefficient $(r=0.183)$ indicates there is a weak correlation between loneliness and the "social networks" dimension. The correlation is statistically significant as shown by $p(\alpha)=0.009$. It means that the higher the level of loneliness experienced by the adolescents, the higher their risk of risk behaviour on social networks. The relationship works vice versa as well: The more risky the adolescents' behaviour on the Internet, the lonelier they feel.

\begin{tabular}{|c||c||c||c|}
\hline & $\mathbf{N}$ & $\mathbf{r}$ & $\mathbf{p}(\boldsymbol{\alpha})$ \\
\hline \hline Loneliness & & & \\
\cline { 1 - 2 } & 200 & 0.183 & 0.00 \\
$9^{* *}$
\end{tabular}

$* * p(\alpha)<0.01$

In the context of this result, further differences identified in loneliness experienced in relation to the time spent by the adolescents on the social networks can be pointed out. The Mann- 
Whitney U-test $(\mathrm{Z}=-3.065)$ shows there are statistically significant differences $(\mathrm{p}(\alpha)=0.002)$ in loneliness depending on the amount of time spent on social networks. The averages show that adolescents who spent more than 6 hours on the social networks a day $(X=2.34)$ score higher in loneliness, i.e. they feel lonelier. The more time adolescents spend on social networks, the more time to share their emotions and thoughts in the form of posting they have. The more time for posting they have, the more the risk that they will start behaving in a risky manner increases. These activities can be perceived as a way to compensate for their loneliness using Internet social networks.

\begin{tabular}{|c||c|c|c|c|c|c|c|}
\hline & $\begin{array}{c}\text { Amount of time spent } \\
\text { on social networks }\end{array}$ & $\mathrm{N}$ & $\operatorname{Med}(\mathrm{x})$ & $\mathrm{X}$ & $\mathrm{U}$ & $\mathrm{Z}$ & $\mathrm{p}(\alpha)$ \\
\hline \hline \multirow{2}{*}{ Loneliness } & less than 6 hours & 133 & 2.10 & 2.11 & 3108.0 & -3.065 & $0.002^{* *}$ \\
\cline { 2 - 8 } & more than 6 hours & 64 & 2.40 & 2.34 & & & \\
\hline
\end{tabular}

$* * \mathrm{p}(\alpha)<0.01$

Another goal was to investigate whether there was a significant correlation between loneliness and the "Internet compulsions" dimension. The correlation coefficient indicates a weak correlation, however, statistically significant. It can be stated that there are statistically significant correlations between loneliness and the "Internet compulsions" dimension. Kolibová (2013) has stated that Internet compulsions undoubtedly relate to the amount of time adolescents spend on the Internet, which can also be considered a risk factor.

Internet compulsions usually takes the form of unregulated online shopping or online gaming. In this research, 14-year old adolescents spent time gaming the most frequently - 4.79 hours daily on average. As for online shopping, 14-year old adolescents also scored the highest -2.07 hours daily on average. Toporcerová (2019) has claimed that playing videogames and using new technologies illustrate how lonely and vulnerable the young people are when they are exploring the digital world.

Intensive and long-term online gaming leads to addiction, and in turn, loneliness.

\begin{tabular}{|c||c||c||c|}
\hline & $\mathrm{N}$ & $\mathrm{r}$ & $\mathrm{p}(\alpha)$ \\
\hline \hline Loneliness & & & \\
\cline { 1 - 2 } & 200 & 0.214 & $0.002^{* *}$ \\
\hline \hline
\end{tabular}

${ }^{* *} p(\alpha)<0.01$

\section{Loneliness and Risk Behaviour on the Internet}

Last but not least, this research investigated whether there were any significant correlations between loneliness and risk behaviour on the Internet. A weak correlation was found between these two variables $(r=0.205)$, however, statistically significant $(p(\alpha)=0.04)$. The results indicate that the lonelier the adolescent feels, the more risky their behaviour on the Internet. There are multiple reasons, e.g. if the adolescents feels lonely in real life for some reason, they seek resources to compensate this deficiency elsewhere. These resources can often be found on the Internet, which offers seemingly quick and effective solutions to the adolescent's problems. The results also indicate that the more risky the adolescent behaves on the Internet, the lonelier they feel. It can be cause by complete involvement in the virtual world, which is a form of risk behaviour on the Internet. On the other hand, loneliness resulting from risk behaviour on the Internet may also relate to exclusion from the peer group that does not agree with the individual's behaviour on the internet. 


\begin{tabular}{|c||c|c|c|}
\hline & $\mathrm{N}$ & $\mathrm{r}$ & $\mathrm{p}(\alpha)$ \\
\hline \hline Loneliness & 200 & 0.205 & $0.04^{*}$ \\
\hline \hline Risk behaviour on the Internet & & & \\
\hline
\end{tabular}

${ }^{*} \mathrm{p}(\alpha)<0.05$

\section{Discussion - Loneliness in Adolescents (and COVID-19)}

Križanová and Verešová (2020) researched experiencing loneliness in adolescents in the context of attachment to their parents and peers. The research file consisted of 305 respondents; 171 females and 134 boys aged 15-20. The goal of their research was to identify the relationship between loneliness experienced by adolescents and their attachment to parents and peers. The UCLA loneliness scale was used to measure loneliness. Qualitatively, the scores in loneliness experienced were divided as follows: 20-30: none to low loneliness; 31-42: moderate loneliness; 43-51: high loneliness; 55-67: very high loneliness; 68-80 extreme loneliness. The minimum and maximum scores on the UCLA scale were 24 and 73 points respectively. The average score was 41.41 points. Therefore, on average, moderate loneliness was measured. On the other hand, in this research the minimum and maximum scores in the same loneliness scale were 22 and 72 points respectively. The average loneliness score in this research was 43.6 points. Moderate average loneliness was identified in this research as well. Both studies were performed at roughly the same time. Lichner's (2018) research aimed to identify how loneliness affects risk behaviour in both traditional and new forms and predict how loneliness and risk in adolescents are correlated. Lichner's research used the UCLA loneliness scale, and the minimum and maximum scores in the study were 20 and 75 respectively. The average loneliness score was 37.41 points.

To sum up, three studies focused on loneliness have been reviewed with the following average loneliness scores: 41.41; 43.6; and 37.41. The higher scores in the first two studies may result from the fact that both were performed in 2020 when the COVID-19 pandemic started. Lichtner's research was performed before the pandemic. The individual differences are also interesting. As mentioned in the introduction, the COVID-19 pandemic is connected with individual isolation from the surrounding world, which may gradually increase loneliness. Although the differences in average loneliness scores are big, they need to be interpreted with the context in mind. The longer the individual isolation, the bigger the differences may become.

\section{Conclusion}

Every adolescent needs a safe and secure space in their life when they face problems they cannot solve on their own. Usually, adolescents seek help in their family. Deep and stable emotional family relationships help the adolescent maintain emotional balance. Besides family, school is also important given the amount of time the adolescent spends there. To feel emotionally stable, the adolescent needs proper conditions, which will support them in developing a healthy identity. Peer relationships also play an important role in this respect. If these components are working properly, problems arise. These can take the form of loneliness since the adolescent's needs are not saturated. The Internet offers lots of opportunities but a sensible approach to its use is necessary otherwise the adolescent may start engaging in risk behaviour.

This research proved certain correlations between risk behaviour on the Internet and loneliness. Statistically significant correlations between loneliness and individual dimensions 
of risk behaviour on the Internet were found. Therefore, it is of key importance to investigate the factors that cause adolescents to start engaging in risk behaviour on the Internet to select appropriate and effective tools for the elimination of such behaviour. These factors should be further researched.

\section{Bibliography}

[1] Banerjee, D., Rai, M. 2020. Social isolation in Covid-19: The impact of loneliness. International Journal of Psychiatry. vol. 66, no. 6, pp. 525-527.

[2] Benkovič, J. 2007. Novodobé nelátkové závislosti. Psychiatria pre prax. vol. 8, no. 6, pp. 263-266.

[3] Blinka, L. et al. 2015. Online závislosti. Praha: Grada Publishing.

[4] Caplan, S. 2007. Relations among loneliness, social anxiety, and problematic Internet use. In: CyberPsychology. Behavior, and Social Networking. vol. 10, no. 2, pp. 234-242.

[5] Čerešník, M., Gatial, V. 2014. Rizikové správanie a vybrané osobnostné premenné dospievajúcich v systéme nižšieho sekundárneho vzdelávania. Nitra: Pedagogická fakulta Univerzity Konštantína Filozofa v Nitre.

[6] Ceyhan, A. A., Ceyhan, E. 2008. Loneliness, depression, and computer self-efficacy as predictors of problematic internet use. CyberPsychology. vol. 11, no. 6, pp. 699-701.

[7] https://www.iuventa.sk/files/vyskumna_sprava_sk.pdf

[8] Hamburger, A. Y. \& E. B. Artzi, 2003. Loneliness and Internet use. Computers in Human Behavior. vol. 19, no. 2003, pp. 71-80.

[9] Kim, J. H., Larose, R., Peng, W. 2009. Loneliness as the Cause and the Effect of Problematic Internet Use: The Relationship between Internet Use and Psychological Well-Being. Cyberpsychology \& behavior: the impact of the Internet, multimedia and virtual reality on behavior and society. vol. 12, no. 4. pp. 451-5.

[10] Kolibová, D. 2013. Virtuálny svet a jeho dopad na psychiku mladého človeka. In: kniha 2013: Výchova a vzdelávania ako nástroj (de)formovania hodnotového systému spoločnosti III. Ružomberok: Verbum, pp. 25-41.

[11] Križanová, S., Verešová, M. 2020. Pripútanie sa k rodičom a rovesníkom a preživaná osamelost' u adolescentov. In: Konvergencie vedeckej činnosti študentov a učitel'ov. Nitra: PF UKF.

[12] Langmeier, J., Krejčířová, D. 1998. Vývojová psychologie.

[13] Lichner, V., Šlosár, D. 2017. Problematické používanie internet u adolescentov v kontextoch teórie a praxe sociálnej práce. Košice: Univerzita Pavla Jozefa Šafárika v Košicicach, Filozofická fakulta.

[14] Lichner, V. 2018. Prežívanie osamelosti ako predictor rizikového správania adolescnetov. Fórum sociální práce. vol. 2 no. 10, pp. 25-39.

[15] Macek, P. 2003. Adolescence. Praha: Portál.

[16] Madro, M., Kohút, M. eds. 2016. Virtuálna generácia neexistuje. Zborník Medzinárodnej vedeckej konferencie VIRTUÁLNA GENERÁCIA.

[17] Margalit, M. 2011. Lonely Children and Adolescents. Israel: Tel-Aviv University.

[18] Miovský, M. et al. 2010. Primární prevence rizikového chování ve školství. Praha: TOGGA.

[19] Morahan-Martin, J., Schumacher, P. 2003. Loneliness and social uses of the Internet. Computers in Human Behavior. vol. 19, no. 2003, pp. 659-671.

[20] Paluckaitè, U., Matulaitienè, K. Ž. 2016. Students' Engagement in Risky Online Behaviour: The Comparison of Youth and Secondary Schools. The European Proceedings of Social \& Behavioural Sciences. vol. 2016, no. 13, pp. 266-273.

[21] Peplau, L. A., Perlman, D. 1982. Theoretical approaches to loneliness. In: L. A. PEPLAU \& D. PERLMAN, eds. Loneliness. A sourcebook of Current Theory, Research and Therapy. Wiley.

[22] Russell, D.W. 1996. UCLA Loneliness Scale (Version 3): Reliability, Validity, and Factor Structure. Journal of Personality Assesment. vol. 66, no. 1, pp. 20-40. 
[23] Tabak, I., Zawadzka, D. 2017. Loneliness and Internet addiction of Polish adolescents. Psychiatria i Psychologia Kliniczna. vol. 17, no. 2, pp. 104-110.

[24] Toporcerová, D. 2019. Živoffline! Príručka pre animátorov a vedúcich spoločenstiev ZKSM v rámci prevencie kyberšikanovania a nadmerného užívania internetu u detí a mládeže. Spišská Nová Ves: Združenie krest’anských spoločenstiev mládeže.

[25] Valcke, M. et al., 2007. Primary school children's safe and unsafe use of the Internet at home and at school: An exploratory study. Computers in Human Behavior. vol. 23, no. 6, pp. 2838-2850.

[26] Yoder, C.V., Virden, T. B., Amin, K. 2005. Internet Pornography and Loneliness: An Association. Sexual Addiction \& Compulsivity. vol. 12, no. 1, pp. 19-44.

[27] Young, K. S. 1999. The research and controversy surrounding internet addiction. Cyber Psychology and Behavior. vol. 2, pp. 381-383.

The paper is a part of the VEGA 1/0285/18 "Rizikové správanie adolescentov ako klientov sociálnej práce $v$ dôsledku ich osamelosti/ Risky behavior of adolescents as clients of social work due to their loneliness" research project. 